\title{
Profil penderita kanker prostat di RSUP Prof. Dr. R. D. Kandou Manado periode tahun 2013-2015
}

\author{
${ }^{1}$ Valdo R. Solang \\ ${ }^{2}$ Alwin Monoarfa \\ ${ }^{2}$ Ferdinand Tjandra
}

\author{
${ }^{1}$ Kandidat Skripsi Fakultas Kedokteran Universitas Sam Ratulangi Manado \\ ${ }^{2}$ Bagian Ilmu Bedah Fakultas Kedokteran Universitas Sam Ratulangi Manado \\ Email: valdorichardsolang@yahoo.com
}

\begin{abstract}
Prostate cancer is a malignant disease of urogenital system which is the second most common type of cancer in men after lung cancer. Prostate cancer is also one of the most common cause of death in male population. There is no database regarding profiles of prostate cancer in Manado. This study was aimed to determine the profile of prostate cancer patients treated at Prof. Dr. R. D. Kandou Hospital Manado in the period 2013 to 2015. This was a descriptive retrospective study in October to November 2016. Samples were taken based on secondary data of the medical record. The results showed that there were 54 patients with prostate cancer, most were found in 2015 (38.9\%), age group 61-70 years old (37.0\%), lived in Manado (33.3\%), graduated Senior High School (64.8\%), retirees (50.0\%), difficult urination (44.4\%), PSA levels $>100 \mathrm{ng} / \mathrm{ml}$ (50.0\%), histopathological of adenocarcinoma (100.0\%), and Gleason score ranging from 8-10 (46.7\%). Based on metastasis, 14 patients had metastasis $(25.9 \%)$.
\end{abstract}

Keywords: prostate cancer, profile, PSA, histopatology, Gleason score

\begin{abstract}
Abstrak: Kanker prostat ialah penyakit keganasan sistem urogenital yang merupakan kanker kedua terbanyak pada pria setelah kanker paru. Kanker prostat juga merupakan salah satu penyebab terbanyak kematian pada populasi pria. Belum ditemukan data tentang profil kanker prostat di Manado. Penelitian ini bertujuan untuk mengetahui profil penderita kanker prostat yang dirawat di RSUP Prof. Dr. R. D. Kandou pada periode 2013-2015. Jenis penelitian ialah deskriptif retrospektif yang dilakukan pada bulan Oktober sampai November 2016. Sampel diambil berdasarkan data sekunder dari catatan rekam medik. Hasil penelitian mendapatkan 54 penderita kanker prostat, paling banyak ditemukan pada tahun 2015 $(38,9 \%)$, kelompok usia 61-70 tahun (37,0\%), berdiam di Kota Manado (33,3\%), tamat SMA $(64,8 \%)$, pensiunan $(50,0 \%)$, keluhan utama sulit buang air kecil $(44,4 \%)$, kadar PSA $>100$ $\mathrm{ng} / \mathrm{ml}$ (50,0\%), jenis adenokarsinoma (100,0\%), dan skor Gleason 8-10 (46,7\%). Berdasarkan metastasis, sebanyak 14 penderita $(25,9 \%)$ mengalami metastasis.

Kata kunci: kanker prostat, profil, psa, histopatologi, skor gleason
\end{abstract}

Kanker prostat adalah penyakit keganasan sistem urogenital yang merupakan salah satu penyebab terbanyak kematian pada populasi pria. Penyakit ini hanya terdapat pada pria karena pada wanita tidak memiliki kelenjar prostat. ${ }^{1,2}$

Secara global, diperkirakan kanker prostat menduduki urutan ke-4 kanker yang paling sering ditemukan pada manusia setelah kanker payudara, paru dan kolorektum sedangkan angka kejadian kanker pada pria, kanker prostat menduduki urutan ke-2 yaitu sekitar 14,8\% setelah kanker paru 16,8\%. ${ }^{3}$ Di tahun 2030, diperkirakan angka kejadian dan mortalitas kanker prostat meningkat sampai 1.700 .000 
dan 499.000 sebagai hasil pertumbuhan populasi global dan peningkatan angka harapan hidup. ${ }^{4}$

Di USA, kanker prostat melampaui kanker paru sebagai kanker yang paling banyak ditemui pada pria: lebih dari 27.360 pria meninggal karena kanker prostat pada tahun 2009. ${ }^{1}$ Estimasi kasus baru 2015 yaitu $220.800 \quad(26 \%)$ dengan angka kematian $27.540 \quad(9 \%) .^{5} \quad$ Diperkirakan 180.890 kasus baru akan terjadi selama tahun 2016 di USA dan sebanyak 26.120 penderita akan mati pada tahun tersebut. ${ }^{6,7}$

Di Indonesia, berdasarkan data Globocan tahun 2012 menunjukan insidens kanker prostat menempati urutan ke-3 kanker pada pria setelah kanker paru dan kanker kolorektum, sedangkan angka kematian menempati urutan ke-4. Untuk kanker pada kedua jenis kelamin, kanker prostat berada pada urutan ke-5, data Globocan 2008 menunjukkan kanker prostat di Indonesia menempati urutan ke$5 .{ }^{3,8}$

Prevalensi kanker prostat di Indonesia tahun 2013 adalah sebesar 0,2 \%o atau diperkirakan sebanyak 25.012 penderita. Provinsi yang memiliki prevalensi kanker prostat tertinggi adalah Yogyakarta, Bali, Sulawesi Utara, dan Sulawesi Selatan yaitu sebesar 0,5\%o. Estimasi jumlah absolut penderita kanker prostat di Sulawesi Utara adalah 601 penderita. $^{9}$

Sejauh ini, faktor risiko yang diketahui terkait dengan terjadinya kanker prostat adalah umur, ras dan riwayat kanker prostat dalam keluarga. Umumnya kanker prostat mengenai pria dewasa tua dengan puncak pada umur 65-75 tahun. Hasil otopsi dari berbagai negara menunjukkan sekitar 15$30 \%$ laki-laki berusia 50 tahun menderita kanker prostat secara samar dengan usia 80 tahun sebanyak 60-70\% laki-laki memiliki gambaran patologi anatomi keganasan prostat. ${ }^{10,11}$

Beberapa faktor risiko yang diduga terkait dengan kanker prostat adalah pekerjaan sebagai petani dan pekerjaan yang memungkinkan terpapar pestisida serta kadmium. Pada penelitian di Prancis, risiko kanker prostat meningkat 2 kali pada peternak dan petani yang terpapar pestisida. Pekerja yang terpapar kadmium juga berisiko kanker prostat karena kadmium merupakan karsinogen. ${ }^{10,12,13}$

Data di USA menunjukkan bahwa lebih dari 90\% kanker prostat ditemukan pada stadium dini, ${ }^{4}$ sedangkan di Indonesia banyak ditemukan pada stadium lanjut karena terjadi keterlambatan diagnosis. ${ }^{8,13}$ Gejala pada kanker prostat berupa keluhan kemih atau retensi, sakit punggung dan hematuria, namun gejala tersebut juga terdapat pada penyakit Benign Prostate Hyperplasia (BPH) sehingga pemeriksaan fisik saja tidak dapat diandalkan. ${ }^{14}$

Samp[ai sekarang belum terdapat data yang menggambarkan profil penderita kanker prostat di Manado. Penelitian ini bertujuan untuk mengetahui profil penderita kanker prostat yang dirawat di RSUP Prof. Dr. R. D. Kandou pada periode 2013-2015.

\section{METODE PENELITIAN}

Jenis penelitian ini ialah deskriptif retrospektif yang dilakukan pada bulan Oktober sampai November 2016. Sampel diambil berdasarkan data sekunder dari catatan rekam medik penderita kanker prostat yang dirawat di RSUP Prof. Dr. R. D. Kandou Manado tahun 2013-2015.

Variabel penelitian yaitu angka kejadian, usia, pekerjaan, kabupaten/kota, tingkat pendidikan, keluhan utama, nilai prostate-specific antigen (PSA), jenis histopatologik, skor Gleason, dan metastasis. Data diolah dan disajikan dalam bentuk teks tabel dan gambar.

\section{HASIL PENELITIAN}

Berdasarkan hasil penelitian yang dilakukan, didapatkan 54 penderita kanker prostat yang dirawat di RSUP Prof. Dr. R. D. Kandou Manado dalam periode 20132015. Pada tahun 2013 ditemukan 14 kasus (25,9\%), tahun 2014 ditemukan 19 kasus $(35,2 \%)$ dan tahun 2015 ditemukan 21 kasus $(38,9 \%)$ (Tabel 1).

Kelompok usia terbanyak ialah usia 61-70 tahun sebanyak 20 kasus $(37,0 \%)$ 
diikuti usia 71-80 tahun sebanyak 18 kasus $(33,3 \%)$ dan yang paling sedikit $<51$ tahun sebanyak 1 kasus $(1,8 \%)$ (Tabel 2).

Tabel 1. Angka kejadian kanker prostat tahun 2013-2015

\begin{tabular}{ccc}
\hline Tahun & $\mathbf{N}$ & \% \\
\hline 2013 & 14 & 25,9 \\
2014 & 19 & 35,2 \\
2015 & 21 & 38,9 \\
Total & 54 & 100,0 \\
\hline
\end{tabular}

Tabel 2. Distribusi kanker prostat berdasarkan usia

\begin{tabular}{ccc}
\hline Usia & $\mathbf{N}$ & $\mathbf{\%}$ \\
\hline$<51$ & 1 & 1,8 \\
$51-60$ & 7 & 13,0 \\
$61-70$ & 20 & 37,0 \\
$71-80$ & 18 & 33,3 \\
$81-90$ & 8 & 14,8 \\
Total & 54 & 100,0 \\
\hline
\end{tabular}

Distribusi kanker prostat terbanyak di Kota Manado sebanyak 18 kasus (33,3\%), diikuti Kabupaten Minahasa sebanyak 10 kasus $(18,5 \%)$, dan yang paling sedikit di Kabupaten Minahasa Tenggara sebanyak 1 kasus (1,8\%) (Tabel 3).

Tabel 3. Distribusi kanker prostat berdasarkan kabupaten/kota

\begin{tabular}{ccc}
\hline Kab/Kota & N & \% \\
\hline Manado & 18 & 33,3 \\
Minahasa & 10 & 18,5 \\
Minsel & 7 & 13,0 \\
Minut & 3 & 5,5 \\
Mitra & 1 & 1,8 \\
Bolmong & 4 & 7,4 \\
Tomohon & 3 & 5,5 \\
Bitung & 4 & 7,4 \\
Sangihe & 2 & 3,7 \\
Luar sulut & 2 & 3,7 \\
Total & 54 & 100,0 \\
\hline
\end{tabular}

Distribusi kanker prostat berdasarkan pendidikan terbanyak ialah tamat SMA sebanyak 35 kasus $(64,8 \%)$ dan yang paling sedikit ialah tamat sarjana sebanyak 4 kasus $(7,4 \%)$ (Tabel 4).
Tabel 4. Distribusi kanker prostat berdasarkan pendidikan

\begin{tabular}{ccc}
\hline Pendidikan & N & $\%$ \\
\hline SD & 8 & 14,8 \\
SMP & 7 & 13,0 \\
SMA & 35 & 64,8 \\
Sarjana & 4 & 7,4 \\
Total & 54 & 100,0 \\
\hline
\end{tabular}

Distribusi kanker prostat berdasarkan pekerjaan yang terbanyak ialah pensiunan sebanyak 27 kasus $(50,0 \%)$ dan yang paling sedikit ialah pekerja lepas, nelayan, dan tukang masing-masin sebanyak 1 kasus $(1,8 \%)$ (Tabel 5).

Tabel 5. Distribusi kanker prostat berdasarkan pekerjaan

\begin{tabular}{lcc}
\hline Pekerjaan & N & \% \\
\hline Petani & 12 & 22,2 \\
Pensiunan & 27 & 50,0 \\
Wiraswasta & 3 & 5,5 \\
Pegawai swasta & 2 & 3,7 \\
Pekerja lepas & 1 & 1,8 \\
Nelayan & 1 & 1,8 \\
Tukang & 1 & 1,8 \\
Lain-lain & 7 & 13,0 \\
Total & 54 & 100,0 \\
\hline
\end{tabular}

Keluhan utama bervariasi, ada yang tunggal, ada yang lebih dari satu. Sulit buang air kecil sebanyak 24 pasien $(44,4 \%)$ diikuti oleh kencing berdarah sebanyak 22 pasien $(40,7 \%)$. Keluhan lainnya ialah: nyeri pinggang sebanyak 3 pasien $(5,5 \%)$, nyeri saat kencing sebanyak 5 pasien $(9,2 \%)$, sering buang air kecil sebanyak 3 pasien $(5,5 \%)$, lemah badan sebanyak 5 pasien $(9,2 \%)$, nyeri perut sebanyak 6 pasien $(11,1 \%)$, nyeri tulang sebanyak 3 pasien $(5,5 \%)$, sulit buang air besar sebanyak 2 pasien $(3,7 \%)$, penurunan kesadaran, nyeri kaki, kaki bengkak, patah tulang, sesak napas, dan pusing masingmasing sebanyak 1 pasien $(1,8 \%$ ) (Tabel 6). 
Tabel 6. Distribusi kanker prostat berdasarkan keluhan utama

\begin{tabular}{lcc}
\hline \multicolumn{1}{c}{ Keluhan utama } & N & \% \\
\hline Sulit BAK & 24 & 44,4 \\
Nyeri pinggang & 3 & 5,5 \\
Penurunan kesadaran & 1 & 1,8 \\
Disuria & 5 & 9,2 \\
Sering BAK & 3 & 5,5 \\
Lemah badan & 5 & 9,2 \\
Hematuria & 22 & 40,7 \\
Nyeri kaki & 1 & 1,8 \\
Nyeri perut & 6 & 11,1 \\
Nyeri tulang & 3 & 5,5 \\
Kaki bengkak & 1 & 1,8 \\
Fraktur & 1 & 1,8 \\
Sulit BAB & 2 & 3,7 \\
Sesak napas & 1 & 1,8 \\
Pusing & 1 & 1,8 \\
\hline
\end{tabular}

Distribusi kanker prostat berdasarkan PSA yang terbanyak ialah PSA $>100 \mathrm{ng} / \mathrm{ml}$ sebanyak 17 pasien $(50,0 \%)$ dan yang paling sedikit ialah $\leq 10 \mathrm{ng} / \mathrm{ml}$ sebanyak 3 pasien $(8,8 \%)$ (Tabel 7).

Tabel 7. Distribusi kanker prostat berdasarkan nilai PSA

\begin{tabular}{ccc}
\hline PSA & N & \% \\
\hline$\leq 10$ & 3 & 8,8 \\
$11-55$ & 6 & 17,6 \\
$56-100$ & 8 & 23,5 \\
$>100$ & 17 & 50,0 \\
Total & 34 & 100,0 \\
\hline
\end{tabular}

Dari 54 total sampel, hanya 23 pasien yang tercatat pemeriksaan histopatologik dan semuanya mempunyai gambaran histopatologi adenokarsinoma. Dari 23 penderita kanker prostat yang terdapat hasil histopatologik, 15 diantaranya dilakukan penilaian skor Gleason yaitu Gleason 2-4 sebanyak 4 pasien $(26,7 \%)$, Gleason 5-7 sebanyak 4 pasien $(26,7 \%)$, dan Gleason 8 10 sebanyak 7 pasien $(46,7 \%)$ (Tabel 8).

Frekuensi penderita kanker prostat berdasarkan metastasis yaitu sebanyak 14 pasien $(25,9 \%)$ dan sisanya yang tidak terdapat metastasis sebanyak 40 pasien
$(74,1 \%)$ (Tabel 9). Kebanyakan metastasis pada tulang namun lokasinya tidak tercatat secara spesifik.

Tabel 8. Distribusi kanker prostat berdasarkan jenis histopatologi dan skor Gleason

\begin{tabular}{ccc}
\hline Histopatologik & $\mathbf{N}$ & $\mathbf{\%}$ \\
\hline Adenokarsinoma & 23 & 100,0 \\
Total & 23 & 100,0 \\
\hline Skor Gleason & $\mathbf{N}$ & $\mathbf{\%}$ \\
\hline $2-4$ & 4 & 26,7 \\
$5-7$ & 4 & 26,7 \\
$8-10$ & 7 & 46,7 \\
Total & 15 & 100,0 \\
\hline
\end{tabular}

Tabel 9. Distribusi kanker prostat berdasarkan metastasis

\begin{tabular}{ccc}
\hline Metastasis & N & \% \\
\hline Ya & 14 & 25,9 \\
Tidak & 40 & 74,1 \\
\hline
\end{tabular}

\section{BAHASAN}

Dari penelitian ini didapatkan penderita kanker prostat terbanyak dijumpai pada tahun 2015 (38,9\%), diikuti tahun $2014(35,2 \%)$, dan yang paling sedikit ialah tahun 2013 (25,9\%). Hal ini menunjukkan terdapat peningkatan jumlah kasus kanker prostat di setiap tahun. Peningkatan kejadian kanker prostat berhubungan dengan usia harapan hidup yang saat ini meningkat setiap tahun sehingga jumlah lanjut usia akan semakin banyak, sementara lanjut usia merupakan salah satu faktor risiko yang penting dalam kejadian kanker prostat. ${ }^{2,15}$

Ditinjau dari usianya, penderita kanker prostat dijumpai mulai dari usia 48 sampai 88 tahun. Hal ini sesuai dengan teori yang mengatakan bahwa terjadinya kanker prostat umumnya dimulai pada usia 50 tahun sehingga deteksi dini pentingn dilakukan pada pria yang berusia kurang lebih 50 tahun atau 40 tahun pada pria yang mempunyai risiko seperti terdapatnya riwayat kanker prostat dalam keluarga. 3,1618 Penderita kanker prostat dengan frekuensi tertinggi ditemukan pada kelompok usia 61-70 tahun $(37,0 \%)$ dan 
paling sedikit pada kelompok usia $<51$ tahun $(1,8 \%)$ yang menunjukkan terjadinya peningkatan kejadian kanker prostat berbanding lurus dengan peningkatan usia. Hal ini sesuai dengan beberapa penelitian sebelumnya yaitu penelitian Siregar ${ }^{19}$ yang menunjukkan kelompok usia terbanyak pada kanker prostat ialah 61-70 tahun $(25,3 \%)$ dari 194 total sampel, dan penelitian Zendrato ${ }^{20}$ yang juga menunjukkan kelompok usia terbanyak pada kanker prostat ialah $61-70$ tahun $(48,9 \%)$ dari 45 total sampel. Berbagai acuan pustaka menyatakan bahwa kanker prostat jarang pada usia $<50$ tahun. $^{3,21}$ Beberapa unsur penting seperti kalsium dan vitamin D menurun pada usia $>50$ tahun yang berakibat osteoporosis. Konsumsi kalsium secara berlebih saat itu dapat memicu terjadinya kanker prostat. ${ }^{10,17}$

Berdasarkan kabupaten atau kota tempat penderita kanker prostat tinggal, didapatkan frekuensi tertinggi ialah Kota Manado (33,3\%) diikuti kabupaten Minahasa (18,5\%) dan frekuensi terendah ialah kabupaten Minahasa Tenggara $(1,8 \%)$. Penelitian di negara bagian Brazil, Sao Paulo menunjukkan tingkat mortalitas tinggi pada pasien yang tinggal di daerah miskin; hal ini mungkin berhubungan dengan kurangnya akses untuk skrining kanker prostat sebagai pencegahan. ${ }^{22}$ Daerah tempat tinggal juga dihubungkan dengan kebiasaan makan atau pola makan tinggi lemak atau banyak mengonsumsi daging merah yang berasosiasi dengan faktor risiko terjadinya kanker prostat. ${ }^{17,18}$

Dilihat dari tingkat pendidikan, didapatkan bahwa sebagian besar penderita kanker prostat berpendidikan tamat SMA $(64,8 \%)$ dan terendah pada tingkat pendidikan tamat sarjana $(7,4 \%)$. Dalam suatu studi retrospektif observasional di Brazil oleh Souza ${ }^{22}$ didapatkan bahwa pasien dengan tingkat pendidikan rendah ( $<8$ tahun pendidikan) 4,8 kali lebih mungkin terjadi metastasis dibandingkan pasien dengan pendidikan yang lebih tinggi (>11 tahun pendidikan). Hal ini mungkin karena penggunaan pelayanan kesehatan yang kurang pada pasien dengan tingkat pendidikan yang rendah. Individu yang tidak mencari pengobatan atau tidak mempunyai akses ke pelayanan kesehatan cenderung terjadi keterlambatan diagnosis. Sebaliknya, individu dengan pendidikan tinggi lebih mungkin untuk melakukan skrining. ${ }^{22}$

Ditinjau dari pekerjaannya, didapatkan frekuensi tertinggi penderita kanker prostat ialah sebagai pensiunan $(50,0 \%)$ diikuti petani $(22,2 \%)$, dan frekuensi terendah pada pekerja lepas, nelayan dan tukang (masing-masing 1,8\%). Berbeda dengan penelitian Zendrato $^{20}$ yang menunjukkan frekuensi tertinggi penderita kanker prostat bekerja sebagai wiraswasta yaitu sebanyak 20 penderita $(44,4 \%)$ sedangkan pensiunan hanya sebanyak 7 penderita $(15,6 \%)$ dari 45 total sampel. Terdapat kesamaan pada penderita yang bekerja sebagai petani yaitu menempati frekuensi tertinggi kedua dan mempunyai persentase yang sama yaitu $22,2 \%$. Beberapa penelitian tentang pekerjaan sebagai faktor risiko terhadap kanker prostat menunjukkan bahwa paparan pestisida yang sering pada petani dapat meningkatkan risiko 2 kali lipat namun hal ini masih kontroversial. ${ }^{9,11}$

Berdasarkan keluhan utama, terdapat variasi gejala yang dialami oleh penderita. Keluhan utama yang paling sering ditemukan ialah sulit buang air kecil (44,4\%) diikuti kencing berdarah yang hanya mempunyai selisih kecil $(40,7 \%)$ sedangkan keluhan utama yang paling sedikit ditemukan ialah penurunan kesadaran, nyeri kaki, kaki bengkak, patah tulang, sesak napas dan pusing yaitu masing-masing hanya terdapat pada 1 penderita saja $(1,8 \%)$. Hal ini menunjukkan bahwa kebanyakan penderita sudah berada pada tahap lanjut, sesuai dengan acuan pustaka yang menyatakan bahwa kebanyakan kanker prostat di negara berkembang sering didiagnosis pada tahap lanjut. ${ }^{23}$ Pada tahap awal kanker prostat sering kali tidak memberikan gejala (asimtomatik) sedangkan nyeri tulang dan patah tulang merupakan gejala yang terjadi pada metastasis. ${ }^{18,24}$

Berdasarkan kadar PSA, dari 54 total 
sampel hanya 34 penderita kanker prostat yang memiliki hasil PSA. Dapat dilihat frekuensi tertinggi terdapat pada PSA $>100$ $\mathrm{ng} / \mathrm{ml}(50,0 \%)$ dan frekuensi terendah terdapat pada PSA $\leq 10 \mathrm{ng} / \mathrm{ml}(8,8 \%)$. Hal ini sesuai dengan penelitian yang dilakukan oleh Erlangga ${ }^{25}$ yang menemukan bahwa frekuensi terbanyak kanker prostat mempunyai nilai PSA >10 ng/ml $(65,9 \%)$. Juga penelitian yang dilakukan oleh Lubis dan Danarto $^{24}$ yang menemukan bahwa frekuensi terbanyak kanker prostat mempunyai nilai PSA $>10 \mathrm{ng} / \mathrm{ml}(87,9 \%)$. Berdasarkan penelitian, PSA dengan nilai ambang batas $4 \mathrm{ng} / \mathrm{ml}$ memiliki sensitivitas $>90 \%$ dan spesifisitas $<25 \%$, sedangkan jika nilai ambang batas $10 \mathrm{ng} / \mathrm{ml}$ spesifitasnya meningkat sampai 2 kali lipat. Hal ini sesuai dengan teori yang mengatakan bahwa semakin meningkatnya produksi PSA menandakan terjadinya peningkatan metabolisme berlebihan pada prostat yang semakin mengarah pada keganasan sehingga pemeriksaan PSA sebagai deteksi dini terhadap kanker prostat. $^{25}$ Peningkatan PSA $>100 \mathrm{ng} / \mathrm{ml}$ sebelum terapi merupakan indikator penting adanya metastasis dengan nilai positif prediktif $100 \%$ sehingga perlu untuk dilakukan pemeriksaan lanjut berupa foto polos tulang, CT atau MRI. ${ }^{21}$ Dalam suatu penelitian, didapatkan bahwa rerata kadar PSA di negara maju lebih rendah seperti Jepang dan Korea Selatan yaitu antara 15$51 \mathrm{ng} / \mathrm{ml}$, sementara di negara berkembang bervariasi dari $75-373 \mathrm{ng} / \mathrm{ml}^{26}$

Berdasarkan gambaran histopatologik, dari 54 total sampel hanya 23 penderita kanker prostat yang memiliki hasil histopatologik dan semuanya menunjukkan gambaran adenokarsinoma (100,0\%); sisanya tidak tercatat atau tidak dilakukan pemeriksaan histopatologik. Hal ini sesuai dengan teori yang menyatakan bahwa lebih dari 95,0\% kanker prostat menunjukkan gambaran adenokarsinoma. ${ }^{18}$

Dari 23 penderita kanker prostat yang terdapat hasil histopatologik hanya 15 penderita yang memiliki skor Gleason, sisanya sukar dinilai atau tidak dilakukan penilaian skor Gleason. Penderita kanker prostat terbanyak memiliki skor Gleason 810 (diferensiasi buruk) yaitu sebanyak 7 penderita $(46,7 \%)$, sedangkan skor Gleason 2-4 (diferensiasi baik), dan 5-7 (diferensiasi sedang) masing-masing sebanyak 4 penderita $(26,7 \%)$. Hal ini sejalan dengan penelitian Putriyuni ${ }^{27}$ yang mendapatkan derajat histopatologik terbanyak ialah diferensiasi buruk $(46,6 \%)$, namun berbeda dengan penelitian yang di lakukan oleh Hendrianto ${ }^{28}$ yang mendapatkan frekuensi tertinggi terdapat pada skor Gleason 5-7 (diferensiasi sedang) yaitu $63,5 \%$.

Untuk metastasis terdapat pada 14 penderita $(25,9 \%)$ dan didominasi oleh metastasis tulang namun lokasi metastasis tidak tertulis secara spesifik. Hal ini sesuai teori yang menjelaskan bahwa penyebaran kanker prostat stadium lanjut terbanyak pada tulang yaitu sekitar $70,0 \%$ yang nanti akan menyebabkan manifestasi nyeri tulang. Patogenesis metastasis kanker prostat ke tulang karena adanya pleksus pembuluh darah vena yang dinamakan pleksus Batson. Aliran darah vena dari prostat akan mengalir ke colum vertebra dan pelvis melalui pleksus Batson sehingga penyebaran kanker prostat banyak ditemukan di tulang vertebra, terutama lumbal dan tulang pelvis. ${ }^{25}$

\section{SIMPULAN}

Berdasarkan penelitian yang dilakukan secara retrospektif di RSUP Prof. Dr. R. D. Kandou Manado dapat disimpulkan bahwa penderita kanker prostat terus meningkat selama 3 tahun terakhir yaitu dari tahun 2013 sampai 2015. Penderita kanker prostat terbanyak pada tahun 2015, kelompok usia 61-70 tahun, bertempat tinggak di Kota Manado, pendidikan tamat SMA, pensiunan, keluhan utama sulit buang air kecil, PSA >100 ng/ml, jenis histopatologik adenokarsinoma, dan skor Gleason 8-10.

\section{SARAN}

Perlu dilakukan deteksi dini pada pria yang berusia 50 tahun atau 40 tahun dengan faktor risiko lain seperti terdapat riwayat kanker prostat dalam keluarga. 
Kelengkapan data rekam medik sangat diperlukan untuk menunjang pendekatan penelitian yang akurat dan berkualitas. Selain itu, perlu dilakukan penelitian lebih lanjut seperti hubungan antar variabel agar dapat memberi informasi mengenai perkembangan penyakit kanker prostat.

\section{DAFTAR PUSTAKA}

1. Xu Y, Jiang YF, Wu B. New agonist and antagonist-based treatment approaches for advanced prostate cancer. J Int Med Res. 2012;40:1217.

2. Chodidjah. Aspek imunologik pada kanker prostat. Sultan Agung. 2009;44:118.

3. International Agency for Research on Cancer. Globocan 2012: Estimated cancer incidence, mortality and prevalence worldwide in 2012. [cited 2016 Aug 28]. Available from: http://globocan.iarc.fr/Pages/fact_sheets _population.aspx.

4. Stephenson AJ, Klein EA. Epidemiology, etiology, and prevention of prostate cancer. In: Wein AJ, Kavoussi LR, Partin AW, Peters CA, editors. Campbell-Walsh Urology (11th ed). Philadelphia: Elsevier; 2016; p. 254364.

5. Siegel RL, Miller KD, Jemal A. Cancer statistics, 2015. CA Cancer J Clin. 2015;65(1):5-29.

6. Siegel RL, Miller KD, Jemal A. Cancer statistics, 2016. CA Cancer J Clin. 2016; 66:7-30.

7. American Cancer Society. Cancer facts and figures 2016. Atlanta: American Cancer Society, 2016; p. 1-4.

8. Ikatan Ahli Urologi Indonesia. Panduan nasional penanganan kanker prostat 2015. Jakarta: Komite Nasional Penanggulangan Kanker, 2015; p. 1-10.

9. Kementrian Kesehatan Republik Indonesia. Infodatin pusat data dan informasi : stop kanker. Jakarta: Kementrian Kesehatan RI, 2015; p. 1-5.

10. Sharma M, Lawson J, Karunanayake C, Dosman JA, Punam P. Prostate cancer, farming and other risk factors: A mini review. J Pros Canc. 2016; 1:109.

11. Saputra MAR, Mahartono. Pria 39 tahun dengan kanker prostat resisten kastrasi yang bermetastasis ke tulang. J Medula
Unila. 2016; 4:93-8.

12. Lemarchand $C$, Tual S, Boulanger $M$, Morlais NL, Perrier S,Clin B, Guizard AV,Velten M,Rigaud E, Baldi I, Lebailly P. Prostate cancer risk among French farmers in the AGRICAN cohort. Scand J Work Environ Health. 2016;42(2):144-52.

13. Roestijawati N. Hubungan kadar kadmium darah dengan karsinogenesis prostat: studi kadar psa, IGF-1 dan polimorfisme gen PSA rs266882 pada kelompok terpapar $\mathrm{Cd}$ dan kelompok tidak terpapar $\mathrm{Cd}$ [Dissertation]. [Yogyakarta]: Universitas Gadjah Mada; 2016.

14. Chodak GW. Prostate cancer. 2016 Aug 03 [cited 2016 Aug 28]. Available from : http://emedicine.medscape.com/article/ 1967731-overview\#a6.

15. Yudha AK. Management of prostate cancer. Medula. 2014;2:15-20.

16. Tate $\mathbf{P}$. Seeley's Principles of Anatomy and Physiology (2nd ed). New York: McGraw Hill, 2012; p. 779.

17. American Cancer Society. Prostate cancer : early detection, diagnosis and staging. Atlanta: American Cancer Society, 2016; p. 1-30.

18. Presti, JC, Kane CJ, Shinohara K, Carrol PR. Neoplasm of the prostate gland. In: Tanagho EA, McAnich JW, editors. Smith's General Urology (17th ed). USA: McGraw Hill Companies Inc, 2008; p. 355-69.

19. Siregar SV. Prevalensi kanker prostat di Laboratorium Patologi Anatomi Fakultas Kedokteran Universitas Sumatera Utara tahun 2009-2010. [Skripsi]. Medan: Universitas Sumatera Utara; 2011.

20. Zendrato DPP. Karakteristik penderita tumor jinak dan ganas pada prostat di Rumah Sakit Umum Pusat Haji Adam Malik Medan tahun 2011 [Skripsi]. Medan: Universitas Sumatera Utara; 2013.

21. Umbas R. Penanganan kanker prostat saat ini dan beberapa perkembangan baru. ndonesian Journal of Cancer. 2008;3:114-9.

22. Souza ABC, Guedes HG, Oliveira VCB, Araujo FA, Ramos CCO, Medeiros KCP, et al. High incidence of prostate cancer metastasis in Afro-Brazilian 
men with low educational levels: a retrospective observational study. BMC Public Health. 2013;13:537.

23. Septiawan AD, Kodariah R, Saraswati $M$. Analysis expression of ZIP1 and caspase-3 protein in adenocarsinoma of the prostate. Makara J. Health Res. 2016;20(1):18-22.

24. Lubis AS, Danarto. Batasan Prostate Specific Antigen (PSA) pada pasien kanker prostat untuk memprediksi metastasis ke tulang di Rumah Sakit Sardjito Yogyakarta. Indonesian Journal of Cancer. 2014;8 :169-72.

25. Erlangga D. Ketepatan diagnostik prostat spesifik antigen pada keganasan prostat di Rumah Sakit Dokter Kariadi Semarang [Skripsi]. Semarang: Universitas Diponegoro; 2007.

26. Umbas R, Mochtar CA, Rahardjo HE. Current status of prostate cancer in Asia. Indonesian Journal of Cancer. 2011;5(1):21-4.

27. Putriyuni A, Hilbertina N. Adenokarsinoma prostat: penilaian prognostik dan derajat histopatologi. MKA. 2014; 37(2):93-100.

28. Hendrianto. Profil penderita adenokarsinoma prostat di Laboratorium Patologi Anatomi Kota Medan tahun 2009 [Tesis]. Medan: Universitas Sumatera Utara; 2010. 